\title{
British and American Canals c.1763 - 1825: Connectivity, Continuity and Change
}

\section{Simon Hill and Daniel Kanhofer ${ }^{1}$}

\begin{abstract}
À la fin du dix-huitième siècle et au début du dix-neuvième, on a beaucoup écrit sur les canaux britanniques et américains. Malgré cela, la documentation analyse rarement ce sujet dans une perspective transatlantique plus large. Les auteurs avancent ici l'argument que les voies de navigation des deux côtés de l'océan reflétaient la connectivité, la continuité et le changement qui s'opéraient dans les relations anglo-américaines entre 1763 et 1825 . En effet, l'an 1763 a marqué la fin de la guerre de Sept Ans et 1825 a vu l'achèvement du canal Érié. La guerre et la révolution ont caractérisé cette période des deux côtés de l'Atlantique. Notre article, qui fusionne deux exposés présentés en 2014 dans le cadre de la conférence de la North American Society for Oceanic History, porte essentiellement sur les interactions socioculturelles et économiques.
\end{abstract}

\section{Introduction}

Connectivity, continuity, and change, were key features in Anglo-American relations during the late eighteenth and early nineteenth centuries. Following the end of the Seven Years War in 1763, Britain consolidated its hold over the thirteen colonies on the American eastern seaboard. These territories were connected to the British Isles through patterns of migration and trade. However, a combination of socio-economic and political factors ignited the Revolutionary War between Britain

\footnotetext{
This article links two presentations delivered at the North American Society of Oceanic History annual conference at Erie, Pennsylvania, 14-17 May 2014. They were "Surpassing the Mother Country of Improvement: The Cultural Stakes of Canal Building in the Early United States" by Daniel Kanhofer, and "Waterways as Conduits of Empire: Merseyside Canals during the American Revolutionary Era" by Simon Hill. The latter thanks Liverpool John Moores University Postgraduate Travel Fund for helping him attend this gathering.
}

The Northern Mariner/Le marin du nord, XXVI, No. 2 (April 2016), 126-44. 
and the thirteen colonies in 1775 . The following year the colonists declared their independence from the mother country, which was finally recognised by London in $1783 .{ }^{2}$ Clearly, the advent of US republicanism marked a significant departure from British monarchism. Tensions also lingered between the two nations for several years. These included disagreements over British relations with Native Americans on the western frontier, as well as disputes over the rights of neutral carriers during the French Wars (c.1793-1815). This resulted in the inconclusive Anglo-American War of 1812. Nevertheless, historians have identified a broader continuity in British and American relations post-1783. P.J. Marshall noted that regardless of political independence, the new republic's largest trading partner was Britain. The US also continued to draw large numbers of migrants from the British Isles. ${ }^{3}$

Canals were another feature of the age. The development of inland waterways in the UK can be traced back to the early modern period. Yet due to commercial necessity, and frustration with the existing road network, the pace of improvement quickened during the eighteenth century. As a result, considerable time and money were spent widening and deepening river channels. Still, this approach was not foolproof as natural barriers caused significant delays. Henceforth, with an increasing population and volume of trade, it became imperative to establish more effective forms of transportation, such as canals. ${ }^{4}$ There were also discussions about canal building in the thirteen colonies during the eighteenth century, but these projects lagged behind those in the UK. It was not until 1800 that the first US canal, the Santee in South Carolina, was opened. ${ }^{5}$ Regardless, the Erie Canal proved to be the "greatest of New World Canals." Completed by 1825, this 363-mile navigation transported agricultural goods from the Great Lakes to New York City. It also attracted an influx of migrants from New England, and spawned the rise of cities such as Buffalo and Rochester. In addition, this waterway marked the rise of New York over other American Atlantic ports, including Philadelphia. ${ }^{7}$

This article casts fresh light on late eighteenth and early nineteenth century canals in Britain and America, by viewing them in a trans-Atlantic context. Indeed, existing literature on the Atlantic world during this period offers little, if any,

\footnotetext{
${ }^{2}$ For background see Anthony McFarlane, The British in the America 1480-1815 (London, 1994) and Francis D. Cogliano, Revolutionary America 1763-1815: A Political History (London, 2000).

${ }^{3}$ P.J. Marshall, Remaking the British Atlantic: The United States and the British Empire after American Independence (Oxford, 2012), 311-21.

${ }^{4}$ Philip Bagwell, The Transport Revolution (London, 1988), 1-3.

${ }^{5}$ Earlier small-scale canal projects in North America were undertaken for military purposes. See John Charles Kendall, "The Construction and Maintenance of Coteau Du Lac: The First Lock Canal in North America," Journal of Transport History, 1, 1 (1971), 39-50.

${ }^{6}$ Charles Hadfield, The Canal Age (Newton Abbot, 1968), 34.

${ }^{7}$ Eric Foner, Give Me Liberty! An American History (London, 2014), 320-4. Also see Ronald E. Shaw, Erie Water West: A History of the Erie Canal, 1792-1854 (Lexington, 1966).
} 
reference to navigable waterways. ${ }^{8}$ We show that canal promotion and construction in the UK and US were mediums of connectivity, continuity, and change, in AngloAmerican relations c.1763-1825. That is not to say that there was a canal that physically connected both sides of the Atlantic. Nevertheless, these waterways did indirectly link the British Isles with North America in at least two key respects. The first was socio-cultural, which we define here as social interaction, a shared sense of identity and belonging, as well as knowledge transferral. Writings by American travellers in the UK prior to the Revolution indicate that these individuals viewed and travelled along British canals (not just roads). Consequently, they gained information about these waterways, and transferred this knowledge back to the colonies. Other colonial travellers expressed pride in British canals, and therefore shared a sense of belonging with the mother country. Even after 1783, there was socio-cultural continuity as early US canal progenitors continued to draw technical inspiration from their British counterparts. That said, however, there were some changes too. Following independence, the US sought to improve upon the former mother country's canal construction legacy. This was a desire on the part of some Americans to assert their post-colonial identities (which, ironically, continued to use perceived British cultural norms as a reference point). ${ }^{9}$

The second key role played by canals in Anglo-American relations during this period was economic. Ships conveyed people and goods from America across the Atlantic to Britain. Yet it was domestic infrastructure, such as canals, that transported American raw materials from British ports to their hinterlands for manufacturing. In return, British manufactures were sent along these canals, and then loaded on board vessels bound for America. Thus, both territories were economically connected. Between 1775 and 1783, military conflict and the internal dynamics along some British waterways threatened to disrupt the trans-Atlantic economic nexus. Yet the Revolutionary War did not stop overseas trade entirely, and British canals continued to transport manufactured goods bound for America even after 1783. In addition, the early republic continued to draw heavily upon British finance, which helped fund US canal construction. However, in a bid to counter perceived British financial influence, American canal advocates changed their funding arrangements. After failed attempts to emulate the traditional British model of private canal companies, Americans channelled canal building money through their own accountable state governments.

\footnotetext{
${ }^{8}$ See David Armitage and Michael J. Braddick, eds., The British Atlantic World 1500-1800 (Basingstoke, 2002) and Ian K. Steele, The English Atlantic 1675-1740: An Exploration of Communication and Community (Oxford, 1986), 273-8.

${ }^{9}$ For more on US post-colonialism see Jack P. Greene "Colonial History and National History: Reflections on a Continuing Problem," William and Mary Quarterly, 64, 2 (2007), 235-50; Kariann Akemi Yokota, Unbecoming British: How Revolutionary America Became a Postcolonial Nation (Oxford, 2011), and Jennifer Clark, The American Idea of England, 1776-1840: Transatlantic Writing (Farnham, 2013).
} 


\section{Socio-Cultural Connectivity between 1763 and 1783}

Between the conclusion of the Seven Years War in 1763 and the emergence of the United States twenty years later, canals indirectly linked Britain and North America in socio-cultural terms. This was evident in the travel writing literature of the period, which showed that American visitors used domestic infrastructure (such as roads) to travel around the British Isles. However, they also observed and used canals for transportation purposes too. Some of these writers were drawn to British canals by their technological potential, which they subsequently shared with their fellow colonists. For other colonial visitors, the achievement of British canals enhanced their connections with the mother country.

One of the best documented examples of these colonial travellers in Britain was Benjamin Franklin. Born in 1706, he "best exemplified the American Enlightenment." Initially making his money as a printer, Franklin was a polymath. He was elected to the Pennsylvania Assembly, and later represented several colonies in London as their agent (1757-1762 and 1766-1774).$^{10}$ In time, Franklin became one of the towering figures of the American Revolution. Nevertheless, during his pre-war residency in the UK, Franklin sought to educate himself in the practicalities of canal construction. In 1760 he used the example of a canal connected to the sea to analyse the flow of tides. Franklin concluded that the water level was not even throughout the navigation, as fluidity and gravity influenced the movement of waves. ${ }^{11}$ Franklin was also curious about how water-depth affected the movement of traffic along canals. Thus, in 1768, he asked the London watermen if there was a difference between rowing in shallow and deep water. The men replied that there was indeed a difference - although they disagreed as to precisely how. ${ }^{12}$ Franklin's activities were also inspired by his trips to British waterways. For example, in 1771 he visited the Duke of Bridgewater's canal in North West England. This navigation was designed to transport coal from the duke's mines in Worsley, near Manchester, to the port-town of Liverpool. During this particular excursion, Franklin sailed on a "luxurious" horse-drawn boat and observed the miners at work. ${ }^{13}$

As evidence of the trans-Atlantic connection, Franklin shared British technological expertise in his letters home to encourage canal construction in America. Writing to the noted Delaware canal advocate Thomas Gilpin in 1770, Franklin observed: "I see...good Remarks on the Advantage of Canals for internal

\footnotetext{
${ }^{10}$ Maldwyn Jones, The Limits of Liberty: American History 1607-1992 (Oxford, 1995), 29-30.

${ }^{11}$ Benjamin Franklin, London, to Mary Stevenson, 13 September 1760, in Leonard W. Labaree, (ed.), The Papers of Benjamin Franklin Volume 9: January 11760 through December 311761 (London, 1966), 213-6.

${ }_{12}$ Benjamin Franklin, Craven Street, to Sir John Pringle, 10 May 1768, in C. Van Doren, (ed.), Benjamin Franklin's Autobiographical Writings (London, 1946), 173-5.

13 "Journal of Jonathan Williams Jr of His Tour with Franklin and Others through Northern England," in William B. Willcox, (ed.), The Papers of Benjamin Franklin Volume 18: January 1 through December 31 1771, (London, 1974), 114-5.
} 
Navigation in our country, to which I heartily wish Success. ${ }^{, 14}$ However, to support these initiatives, Franklin drew inspiration from British precedents. He informed his fellow colonists about the state of the canal building industry in the British Isles. In 1772 Franklin wrote to Samuel Rhoads, a future mayor of Philadelphia, that in Britain "many Canals on foot here... are daily raising a number of Pupils in the Art." Still, Franklin was not always the bearer of good news. In the same letter, he noted that there had been problems with the "great Canal" in Ireland (presumably the Newry). Henceforth, workers had come to "rectify their Errors." 15 Ben Franklin also sent pamphlets on British canals and their designers back across the Atlantic. Such information contained "a great deal of Instruction to... unexperienced Americans." "16 Franklin even explored the possibility of British subjects working on American canals. Writing to P.P. Burdett, a surveyor for the Leeds-Liverpool Canal, Franklin speculated that "a man of your Talents [would be] a great Acquisition to the colonies." 17

Even on the other side of the Atlantic, there was a demand for British canal building expertise. In 1771 Rhoads informed Franklin that there was talk of constructing a new navigation in Pennsylvania, to prevent Philadelphia from succumbing to rising competition from Baltimore, Maryland. Because Berks County, Pennsylvania, contained abundant quantities of limestone suitable for construction purposes, Rhoads expected Philadelphia to be "Canal mad."" Thus, by 1772, Rhoads used the British-based Franklin as an advisor for American canal building schemes. The former enquired if Franklin thought that the Schuylkill River should become "part of a navigation to [the] back country." To this, the latter vaguely responded that British canal designers constantly looked at the practicalities of their projects. ${ }^{19}$

Yet, despite these initiatives, even Franklin was aware of the limitations of American canal building during the colonial period. He doubted "whether [the colonial] Population and internal Commerce [was] sufficient to bear the expense." 20 Rhoads summarised the status of colonial canal building in 1772: American canals were once "look'd on as a wild Chemerical [sic] Project which all the Strength of America could never execute. Now it is hoped for in time to come." ${ }^{21}$ Indeed it would.

${ }^{14}$ Benjamin Franklin, London, to Thomas Gilpin, 18 March 1770, in Willcox, (London, 1973), 17: 103.

${ }_{15}$ Benjamin Franklin, London, to Samuel Rhoads, 22 August 1772, in Willcox, (London, 1975), 19: 278-9.

${ }^{16}$ Samuel Rhoads, Philadelphia, to Benjamin Franklin, 30 May 1772, ibid., 157.

${ }^{17}$ Benjamin Franklin, London, to B.B. Burdett, 21 August 1773, in Willcox, (London, 1976), 20 : 371.

${ }_{18}$ Samuel Rhoads, Philadelphia, to Benjamin Franklin, 3 May 1771, in Willcox, 18: 93-5.

${ }^{19}$ Benjamin Franklin, London, to Samuel Rhoads, 22 August 1772, in Willcox, 19: 278-9.

${ }^{20}$ Franklin to Burdett, 21 August 1773, in Willcox, 20: 371.

${ }^{21}$ Samuel Rhoads, Philadelphia, 30 May 1772, to Benjamin Franklin, in Willcox, 19: 157. 
Other American colonists were impressed by British canals too, even during the war years of 1775-1783. Jabez Maud Fisher was a son of Joshua Fisher, one of the wealthiest Quaker merchants in Philadelphia. ${ }^{22} \mathrm{Jabez}$ is a useful case study because, despite the pacifistic tendency of many Quakers, he emerged as one of Philadelphia's most active conservatives prior to the War of Independence. He is therefore used here as a contrast with the revolutionary Benjamin Franklin. The official reason for Fisher's visit to Britain and mainland Europe between 1775 and 1779 was to settle the accounts of the family firm, and to establish new business networks. But, in all likelihood, it was an attempt by the father to protect his son from the violence engulfing the colonies. During his time in Britain, Jabez visited several locations such as the Lake and Peak Districts, as well as urban destinations like London and Edinburgh. ${ }^{23}$ Jabez also encountered several canals in the British Isles. In October 1775 he observed an unfinished project near Glasgow. ${ }^{24}$ The following year Fisher remarked that the grand canal between Dublin and Limerick was the "widest, the deepest, and the prettiest" he had seen. ${ }^{25}$

Nevertheless, the canals of northern England clearly drew Fisher's attention. This is no surprise, as the North West was Britain's "first industrial region." Indeed, the region contained a service sector with manufacturing interests. ${ }^{26}$ By the $1750 \mathrm{~s}$, Liverpool was emerging as a major industrial town within the regional mineral economy, processing Cheshire salt and consuming Lancastrian coal. ${ }^{27}$ Liverpool was also a significant component within the broader overseas economy. By the 1740s this port town had overtaken London and Bristol as the leading British slave trading port, and by mid-century Liverpool was second only to London in terms of the volume of its North American commerce. ${ }^{28}$ Liverpool's Mersey Estuary was also "the cradle of the canal age." ${ }^{.29}$ Legislation in the early eighteenth century permitted navigation improvements to local rivers such as the Mersey, Douglas, Irwell, and Weaver. The Sankey Brook project, which opened near Liverpool in 1757, arguably became the first modern British canal. Yet the local waterway that attracted the most public attention was the aforementioned Bridgewater Canal. Opened in 1760s, this project established the technological possibilities and commercial viability of navigable waterways around the country. The largest infrastructure project

\footnotetext{
${ }^{22}$ Kenneth Morgan, "Introduction," in Kenneth Morgan, (ed.), An American Quaker in the British Isles: The Travel Journals of Jabez Maud Fisher 1775-1779 (Oxford, 1992), 1-3.

${ }^{23}$ Ibid., 3-24.

${ }^{24}$ Journal B, 10 October 1775, in Morgan, 67-8.

${ }_{25}$ Journal H, 24 April 1776, in Morgan, 167-8.

${ }^{26}$ Jon Stobart, The First Industrial Region: North West England c.1700-60 (Manchester, 2004), 220.

${ }^{27}$ Ibid., 130-3.

${ }_{28}$ P.G.E. Clemens, “The Rise of Liverpool 1665-1750," Economic History Review, 29,2 (1976),

216-7 and Kenneth Morgan, "Liverpool's Dominance in the British Slave Trade 1740-1807," in

David Richardson, Suzanne Schwarz, and Anthony Tibbles, eds, Liverpool and Transatlantic

Slavery (Liverpool, 2007), 14-34.

${ }^{29}$ Bagwell, Transport Revolution, 3.
} 
undertaken in this region during the period was the Leeds-Liverpool Canal. Authorised in 1770 and taking forty-six years to complete, this scheme was originally conceived by Yorkshire businesses intent upon selling their textiles over a wider geographical area. Equally, Liverpool sought to boost its access to Lancashire's coalfields. Consequently, a navigable cut was built between Liverpool and Leeds, which linked the North West and Yorkshire regions. ${ }^{30}$ In October 1775 Jabez visited Liverpool, noting that the port was "by far the most convenient in Great Britain." 31 Thereafter, he embarked upon an excursion along the Bridgewater. ${ }^{32}$ By April 1776 Fisher was in Leeds, and examined the canal that connected the town with Liverpool. ${ }^{33}$ That July Fisher returned to the North West, and travelled down the Bridgewater Canal again. ${ }^{34}$

Like Franklin before him, Fisher described and analysed Britain's canals. In October 1775 Fisher referred to the "fine aqueduct" that supported the Bridgewater Canal over a valley. This structure was buttressed by "a number of fine Arches and the Scene is realy [sic] beautiful." 35 The following year Fisher again praised the technological skill of the Bridgewater. It"unlike...other [canals] in England is without Locks, so that there is no detention whatever, nor any Sort of impediment to the Navigation." ${ }^{36}$ Furthermore, highly skilled individuals were responsible for its construction. Fisher believed that the canal's surveyor, James Brindley, possessed "innate knowledge of Mechanics and Hydraulics." Brindley also deserved praise for his frugality. ${ }^{37}$ In addition, Fisher praised the gentility of travelling along the Bridgewater. The consumption of food and drink on this waterway had rendered his journey "a most comfortable repast." 38

However, whereas Franklin figuratively connected both sides of the Atlantic by sending information on British canals back to America, Fisher used the UK's canals as a medium through which he felt pride and attachment to the mother country. Fisher the loyalist observed that the Leeds-Liverpool Canal appealed to a sense of unity and patriotism. This waterway had faced considerable financial strains, and disputes over its precise route. Nevertheless, these obstacles had been overcome "by the public Spirit of Men in every part of the Nation," who in turn were motivated by "truly patriotic Motives." Additionally, Fisher used imperial terminology to illustrate his points - the construction of the Leeds-Liverpool Canal ensured that

\footnotetext{
30 Sheila Marriner, The Economic and Social Development of Merseyside (London, 1982), 17-22.

31 Journal C, 26 October 1775, in Morgan, American Quaker, 81-2.

32 Ibid., 28 October 1775, in Morgan, American Quaker, 83.

33 Journal G, 14 April 1776, in Morgan, American Quaker,155-8.

34 Journal M, 24-31 July 1776, in Morgan, American Quaker, 232-6.

35 Journal C, 28 October 1775, in Morgan, American Quaker, 83.

36 Journal M, 29 July 1776, in Morgan, American Quaker, 233.

37 Ibid., 30 July 1776, in Morgan, American Quaker, 234.

38 Ibid., 29 July 1776, in Morgan, American Quaker, 233.
} 
"The Irish and German Ocean will...be open to each other and advantages innumerable will flow from so laudable a plan to every part of this Empire." ${ }^{39}$

\section{Socio-Cultural Continuity and Change after $\mathbf{1 7 8 3}$}

British canals continued to feature in American travel writing literature after 1783. For example, when looking back at his time in Britain during the early nineteenth century, the US naturalist J.J. Audubon recalled that he had crossed several canals in Manchester and Derbyshire. ${ }^{40}$ Henry Blake McLellan, a Harvard graduate who was continuing his studies in Edinburgh during the 1830s, also wrote that Lancashire canals were key "points of interest and distraction." Americans continued to find the waterways around Liverpool noteworthy too. McLellan wrote that these channels and the port's docks "glide with streams of silver into deep treasure-houses." ${ }^{" 11}$ Nevertheless, there were some changes in these sources. When compared to American travel literature of the late-eighteenth century, there are noticeably fewer references to British canals during the early-nineteenth century. Nathaniel Parker Willis's 1835 Pencillings by the Way provides an explanation for this. Although Willis, an American author, did mention the Caledonian Canal, his attention was drawn towards a newer form of transportation. Willis recalled that the experience of leaving Liverpool for Chester by train was a transformative experience. The speed of this new technology instilled in Willis "a contempt for time and distance." ${ }^{42}$ Willis was not alone, as other contemporary American sources mention British rail transportation too. ${ }^{43}$ This was surely a sign that the British canal age was giving way to the railway age. In addition, American travel writers increasingly compared their nation's own canal building endeavors with those of the UK - and sometimes with lukewarm comparisons. Herman Melville's semiautobiographical Redburn mentioned that when one saw the Leeds canal in Liverpool, "no one could have told it from the Erie Canal at Albany." ${ }^{44}$

The writings of Americans back in the US also indicate that British canals mirrored continuity and change in Anglo-American socio-cultural relations after independence. The early republic still relied upon the transferal of British technological expertise for canal construction at home, and navigable waterways

\footnotetext{
39 Journal G, 14 April 1776, in Morgan, American Quaker, 157.

${ }^{40}$ Maria R. Audubon, (ed.), Audubon and His Journals Volume One (New York, 1897), 117, 123, 137, located at https://archive.org/details/audubonhisjourna01audu; accessed 1 December 2015.

${ }^{41}$ Henry B. McLellan, Journal of a Residence in Scotland, and Tour Through England, France, Germany, Switzerland and Italy with a Memoir of the Author (Boston, 1834), 107, 123; located at https://data.historicaltexts.jisc.ac.uk/; accessed 1 December 2015.

${ }^{42}$ Nathaniel Parker Willis, Pencillings by the Way (London, 1842), 418, 451, located at https://books.google.co.uk/books; accessed 1 December 2015.

43 McLellan, 108-11; accessed 1 December 2015.

${ }^{44}$ Herman Melville, Redburn: His First Voyage (New York, 1849), located at http://www.gutenberg.org/files/; accessed 1 December 2015.
} 
symbolized a continued affinity with the former mother country. Granted, contemporary US publications made reference to ancient Chinese and Egyptian canal projects, as well as contemporaneous ones in mainland Europe. Still, they often elevated Great Britain as the exemplar of the economic benefits a country could derive from canals. This was evident in both the northern and southern states. In 1803 a Virginian newspaper correspondent asserted: "The high rank which G[reat] Britain hold among the nations of Europe, is owing to her roads and her canals. ${ }^{, 45}$ Equally, one engineer told the New York State Canal Commission in 1812 that Britain was still "the Mother Country for every improvement in the Arts." "46 Furthermore, Americans perceived the benefits of infrastructure by pointing to the British example. In 1817 a promotional tract for the Erie Canal declared that Britain was "the greatest commercial power that ever existed, and has found her canal navigation of the last consequence to her commercial prosperity." ${ }^{47}$

US canal advocates continued to cite the names of prominent British canal projectors and engineers as technological heroes. Pennsylvania and New York newspapers reprinted glowing accounts of the aforementioned James Brindley, celebrating him as the progenitor of Britain's canal age. ${ }^{48}$ Americans also deployed Brindley's name as shorthand for scientific ingenuity, akin to similar usage of the nation-builder and inventor Benjamin Franklin. ${ }^{49}$ Erie Canal engineer James Geddes explicitly glorified his own exploits with reference to Brindley. When reflecting upon his own plan of an embankment for the canal through the Irondoquoit Valley in western New York (to overcome the difficulties of a sharp change in elevation), Geddes "felt disposed to exclaim Eureka, on making this discovery." He continued: "How would the great Brindley, with all his characteristic anxiety to avoid lockage, have felt in such a case[?]"50 And at the New York Coffee House in November 1825, when New York City celebrated the opening of the entire length of the Erie Canal between Albany and Buffalo, one toast included the aforementioned Duke of Bridgewater as one of the "efficient patrons of Canals." 51

As Ben Franklin had done prior to 1775, Americans after independence continued to rely upon British technological knowledge and social networks to

\footnotetext{
${ }^{45}$ Alexandria Expositor (Virginia) republished in Mirror of the Times (Wilmington, Delaware), 4 May 1803.

46 John Stevens to Canal Commissioners in New-York Historical Society, Canal Commissioners Minutes No. 1, May 1811 - March 1812, BV New York, 24 February 1812.

${ }^{47}$ Charles G. Haines, Considerations on the Great Western Canal, from the Hudson to Lake Erie; with a View of Its Expence, Advantages, and Progress (Brooklyn, 1818), 56.

${ }^{48}$ Poulson's American Daily Advertiser (Philadelphia), 25 November 1800. Also see memoir of Brindley in Albany Gazette, 28 March 1793.

49 American Watchman (Wilmington, Delaware), 15 August 1810.

50 James Geddes to William Darby, 22 February 1822 in Laws of the State of New York, in Relation to the Erie and Champlain Canals, Together with the Annual Report of the Canal Commissioners, and Other Documents, Requisite for a Complete Official History of those Works (Albany, 1825), 1: 44.

${ }^{51}$ New-York Spectator, 11 November 1825.
} 
promote their own canal building activities. To do this, aspiring US engineers and projectors deployed several strategies that relied upon traditional methods. Firstly, Americans such as Joshua Gilpin, Robert Fulton, and William Tatham, studied British canals up close in the 1790s, and gained technological knowledge. Gilpin, a Delaware grain merchant, paper manufacturer, and son of Franklin's correspondent, arrived in London in 1795. He soon became acquainted with Fulton, a painter turned aspiring civil engineer. ${ }^{52}$ Tatham was an English immigrant to North America and patriot during the Revolution, who sought employment as a civil engineer in Britain. ${ }^{53}$ All three became eager students of British canal building. Gilpin kept a journal of the canals that he visited, and collected printed works on waterways such as acts of incorporation of British canal companies. ${ }^{54} \mathrm{He}$ hoped to return home to lead the effort to build a canal between the Chesapeake and Delaware Bays. Both Fulton and Tatham published books in London, which promoted new methods of moving boats between the different levels of canals on a more cost effective basis. $^{55}$

Crucially, all three of these aspiring American canal builders sought to integrate themselves into British society. For them, this was a world that represented the cutting edge of "improvement." This concept encompassed notions of moral and scientific progress, which were linked to technological, agricultural, and commercial gains. ${ }^{56}$ These Americans hoped to leverage their access to the British imperial center, so as to join a common trans-Atlantic project of economic improvement. To facilitate his entry into British society, Tatham presented the task of building canals as a truly Anglo-American endeavor. His treatise on canal building noted that Americans and Britons in British North America (Canada) were "people of the same manners, habits, language, pursuits, and hymeneal inclinations." Henceforth, they should collaborate to build navigable waterways. ${ }^{57}$ Tatham proposed the fantastic scheme of a joint Anglo-American project to build an inclined plane canal over

\footnotetext{
${ }^{52}$ See H.W. Dickinson, Robert Fulton Engineer and Artist: His Life and Works, (Edinburgh, 1913).

${ }_{53}$ G.M. Herndon, William Tatham, 1752-1819: American Versatile, (Johnson City, 1973), 162-3.

${ }^{54}$ [Canals] in Pennsylvania State Archives, Joshua and Thomas Gilpin Collection, Journals and Notebooks of Joshua Gilpin, vol. 55, n.d. and Historical Society of Pennsylvania, Gilpin Family Papers, Pamphlets, Plans, Etc. Concerning Waterways and Railways, 1789-1863.

${ }_{55}$ Robert Fulton, A Treatise on the Improvement of Canal Navigation; Exhibiting the Numerous Advantages to Be Derived from Small Canals (London, 1796) and William Tatham, The Political Economy of Inland Navigation, Irrigation and Drainage, with Thoughts on the Multiplication of Commercial Resources, and on Means of Bettering the Condition of Mankind by the Construction of Canals, (London, 1799).

${ }_{56}$ See Richard Drayton, Nature's Government: Government, Science, Imperial Britain, and the Improvement of the World (New Haven, 2000), 51-64; Jack P. Greene, The Intellectual Construction of America: Exceptionalism and Identity from 1492 to 1800 (Chapel Hill, 1997), 11729; and Greene, Pursuit of Happiness: The Social Development of Early Modern British Colonies and the Formation of American Culture, (Chapel Hill, 1988), 197-8.

${ }_{57}$ Tatham, The Political Economy of Inland Navigation, 64-9.
} 
Niagara Falls. He envisioned it as a means to bridge the post-Revolutionary political divide between Britons in Canada and their brethren in the United States. ${ }^{58}$ In addition, Gilpin used family contacts, fellow Quaker merchants, and former American loyalists, to gain access to the sites that he visited. ${ }^{59}$ Both Gilpin and Fulton sought out the famed Duke of Bridgewater, and visited his canal. ${ }^{60}$ Gilpin and Fulton associated simultaneously as allies and competitors of figures such as the British aristocrat and inventor Charles Stanhope. Stanhope was a lonely voice of opposition in the House of Lords to war against revolutionary France, and his critique of the conflict encompassed investigations into improved methods of canal building. ${ }^{61}$ Henceforth, Fulton and Stanhope collaborated to reduce the costs of constructing locks and supplying water through the use of inclined planes. The former hoped that this would facilitate canal construction over large distances across America. ${ }^{62}$ As Stanhope wrote to Fulton: "I hope you will make Canals of Thousands of Miles in America." ${ }^{\prime 63}$ In the event, neither of Fulton's or Stanhope's plans were fully executed. Fulton's plan for canals over mountains was viewed as impracticable by contemporaries.

In the wake of the Revolution, as well as the War of 1812, waterways symbolised Anglo-American unity and rapprochement. Dinners celebrating the progress of New York's canal construction were occasions to build good will between the British Empire and USA. At such an event in 1823, a gentleman in New York City toasted: "The locks of the Canal - may they ever open a free and friendly intercourse between the United States and Canada." ${ }^{64}$ This theme of AngloAmerican unity was also on display in New York harbor in November 1825, when

\footnotetext{
${ }^{58}$ Ibid., 101-4.

${ }^{59}$ Amongst those with whom he socialized were Joseph Galloway, John Delancey, the Penn family, and Benjamin Franklin's exiled son, William. Joshua Gilpin to Miers Fisher, Historical Society of Pennsylvania, Miers Fisher Papers, Box 4, 14 August 1795 and William Franklin to Joshua Gilpin, Historical Society of Pennsylvania, Gilpin Family Papers, vol. 50, 31 August 1797 and vol. 51, 21 March 1799.

${ }^{60}$ Dickinson, Fulton, 30 and 40 and [Canals] in Pennsylvania State Archives, Joshua and Thomas Gilpin Collection, Journals and Notebooks and Joshua Gilpin, vol. 55, n.d. On Gilpin's tour of the Bridgewater Canal see H.B. Hancock and N.B. Wilkinson, "Joshua Gilpin: An American

Manufacturer in England and Wales, 1795-1801 - Part I," Transactions of the Newcomen Society, 32, 1 (1960), 28.

${ }^{61}$ G.M. Ditchfield, "Stanhope, Charles, Third Earl Stanhope (1753-1816)," in Oxford Dictionary of National Biography, H.C.G. Matthew and Brian Harrison, eds. (Oxford, 2004); online ed., Lawrence Goldman, (ed.), January 2008, http://www.oxforddnb.com/view/article/26241; accessed 19 March 2014.

${ }^{62}$ See Kent History and Library Center, Stanhope of Chevening Papers, Letters from Robert Fulton regarding steam navigation. Also see Fulton, $A$ Treatise on the Improvement of Canal Navigation, 132-43 and Robert Fulton to Charles Stanhope, New-York Historical Society, LeBoeuf Collection, 2 May 1805.

${ }^{63}$ Charles Stanhope to Robert Fulton, Kent History and Library Center, Stanhope of Chevening Papers, 24 May 1796.

${ }^{64}$ New-York Spectator, 14 October 1823.
} 
the city celebrated the opening of the entire length of the Erie Canal between Albany and Buffalo. During the ceremonial "wedding of the waters," New York Governor DeWitt Clinton and other dignitaries poured water from Lake Erie and other global waterways into the Atlantic Ocean. When Dr. Samuel Mitchill, an American physician who had studied in Edinburgh, poured water from the River Thames it doubled as a symbolic reconciliation between two former opponents. One observer reported: "[t]he mingling was understood as the sign of a cement between nations which ought never to have been divided; but having been separated by destiny, ought, nevertheless, always to cultivate the best relations. ${ }^{.65}$ New York's celebrants likely borrowed the wedding of the waters from a similar ceremony performed at the opening of Scotland's Forth and Clyde Canal in $1790 .{ }^{66}$ Some Britons expressed similar sentiments about the meaning of US canal building for Anglo-American relations. An essay in the London Times assured readers that, rather than fearing the rise of the United States as represented by the Erie Canal, they should celebrate it. Their "descendants" were "establishing a vast empire in the western hemisphere, where the English language, English habits, and English freedom are to predominate. ${ }^{.67}$

That the Americans should continue to draw heavily from the British example, even after independence, is not surprising. In particular, literary scholars have noted "England was America's closest cultural neighbour and undoubtedly the greatest single outside influence upon her early cultural development. ${ }^{168}$ One academic goes as far as asserting that latent feelings of "Anglophilia" continued to shape aspects of American national identity well into the nineteenth century. For example, US Abolitionists were inspired by the British precedent of having abolished the transAtlantic slave trade in $1807 .{ }^{69}$

Nevertheless, despite the continuity of US canal advocates following British technological and social precedents, there was at least one appreciable difference between canal building in the early republic and colonial period - the intended political outcome. Indeed, whereas during the early-1770s Franklin and Rhoads intended to follow the mother country's example, by the nineteenth century a new breed of US canal advocates hoped to out-perform Britain. Turner Camac was an Irish émigré and Philadelphia-based canal advocate in the early-nineteenth century. He called for an imitation of the British example to expedite the commercial

\footnotetext{
${ }^{65}$ Cadwallader D. Colden, Memoir at the Celebration of the Completion of the New York Canals (New York, 1825), 277.

${ }^{66}$ James Hopkirk, Account of the Forth and Clyde Navigation, from its Origins to the Present Time (Glasgow, 1816), 31. A correspondent of Governor DeWitt Clinton of New York forwarded this pamphlet to him in 1817. Thomas Wilson to DeWitt Clinton, Columbia University Rare Book and Manuscript Library, DeWitt Clinton Papers, vol. 7, 20 March 1817.

${ }^{67}$ The Times (London), 8 September 1819.

${ }^{68}$ Clark, American Idea of England, accessed using Google Books.

${ }^{69}$ Elisa Tamarkin, Anglophilia: Deference, Devotion and Antebellum America (London, 2007), xxix-xxx.
} 
development of an American canal network. But Camac's wording also doubled as a call for the United States not just to emulate Great Britain's commercial success, but also to improve upon it. Here, active government promotion and financing of inland waterways would assure that the US superseded Britain's commercial power, and secure American independence. Camac viewed canal building as a crucial element in US statecraft. While federal planning of a national canal network failed in the early-nineteenth century, state political and civic leaders took up Camac's call for US governments to pursue canal construction. After President Madison vetoed a national transportation funding bill in 1817, New York's canal movement pushed the state to finance the Erie Canal on its own. With a competitive eye towards Britain, as well as each other, individual states directly funded most canals in the US during the height of canal construction, between 1817 and the financial panic of $1837 .{ }^{70}$ State canal promoters pointed to the writings of Camac, who asserted that had England invested public money in canals sooner than the 1760s, "her progress...would have been accelerated, and her prosperity would have risen....at least to a very considerable and even surprising height above her present attainments." "England has made canals, let canals make America.",71

Americans later lauded the Erie Canal with bombastic declarations that contrasted US waterways with those of the Old World. These became common in the toasts, odes, and speeches that memorialized the opening of the Erie Canal. In 1825 American newspaper correspondent William Stone declared that as it looked across the Atlantic, "Europe already begins to admire...that [Americans] have built the longest canal in the world in the least time, with the least experience, for the least money, and to the greatest public benefit."72 This evidence supports the argument that even as Americans sought to portray the US as an independent postcolonial nation gradually ridding itself of British influence, socio-cultural linkages between the Old and New Worlds persisted. As Yokota phrased it, the Americans would undergo a process of "unbecoming British" through the creation of the American genius (whilst paradoxically the US still depended upon living up to Britain's example). ${ }^{73}$ Needless to say, canal construction marked a significant contribution towards the development of a US technological and educational genius. But the extent of American canal building during the early nineteenth century should be put into perspective. Considering the longer history of canal construction,

\footnotetext{
${ }^{70}$ On state canal initiatives and the limitations of US federal infrastructure projections, see Carter Goodrich, Government Promotion of American Canals and Railroads, 1800-1890 (New York, 1960) and John Lauritz Larson, Internal Improvement: National Public Works and the Promise of Popular Government in the Early United States, (Charlotte, 2001).

${ }_{71}$ Turner Camac, Facts and Arguments Respecting the Great Utility of an Extensive Plan of Inland Navigation in America, (Philadelphia, 1805), 54.

${ }^{72}$ William L. Stone, "Narrative of the Festivities Observed in Honor of the Completion of the Grand Erie Canal, Uniting the Waters of the Great Western Lakes with the Atlantic Ocean" in Colden, Memoir at the Celebration of the Completion of the New York Canals, 331.

73 Yokota, Unbecoming British, 10-8.
} 
the United States was a late arrival. By the time that the Erie Canal had opened, for well over a century state officials, individuals, and corporations in France, the Netherlands, and Great Britain, had constructed extensive canal networks. ${ }^{74}$

\section{Economic Connectivity between 1763 and 1783}

In addition to socio-cultural ties, canals reflected economic connectivity between Britain and America. As noted above, Liverpool and the North West region were significant for trans-Atlantic trade and canal transportation. Henceforth, we will use this area as a case study to illustrate our points. Some general facts are well known about the waterways in eighteenth century Liverpool and its hinterland. In particular, trade grew at different rates on different canals, and the flow of traffic was not equal in both directions. ${ }^{75}$ Furthermore, coal, salt, and limestone, were amongst the principal commodities moved along these navigations for domestic consumption. ${ }^{76}$

Crucially, these waterways linked Liverpool and its hinterland to the Americas in a multi-stage process. It initially involved the importation of goods from America into Liverpool, such as New England timber, Pennsylvanian ore, Virginian tobacco, North Carolinian tar, and rice from South Carolina. ${ }^{77}$ The next stage was the shipping of these commodities along canals to the town's manufacturing hinterland. Then these manufactured goods were moved along canals from the hinterland to Liverpool, and from thence exported to America. For example, Wigan's iron industry obtained metal ore via the port of Liverpool and the Leeds-Liverpool Canal, and some of this ironware and machinery was subsequently exported to North America and the Caribbean. ${ }^{78}$ Consequently, the Mersey canal system not only linked Liverpool with its domestic hinterland, but also connected the wider North West economy to overseas and North American markets.

The American Revolutionary War affected Liverpool's overseas trade with the thirteen colonies. Indeed, right at the very start of the conflict, Liverpool vessels still sailed to these territories. ${ }^{79}$ But there was a subsequent downturn in trade. As British authority in the colonies collapsed, the US Congress took over. The resulting

\footnotetext{
${ }^{74}$ For mainland European canal projects see Jan De Vries, Barges and Capitalism: Passenger Transportation in the Dutch Economy, 1632-1839 (Utrecht, 1981) and Chandra Mukerji, Impossible Engineering: Technology and Territoriality on the Canal Du Midi (Princeton, 2009). 75 J. Langton, "Liverpool and its hinterland in the late eighteenth century," in B.L. Anderson and P.J.M. Stoney, eds., Commerce, Industry and Transport: Studies in Economic Change on Merseyside, (Liverpool, 1983), 7-9.

${ }^{76}$ British Library, Summary View of the Proposed Canal from Leeds to Liverpool, RB 23.A.5810, 1768.

77 Liverpool General Advertiser, 10 June 1774.

${ }^{78}$ Langton, "Liverpool and its hinterland in the late eighteenth century," 11-2. Also see Williamson's Liverpool Advertiser, 28 November 1766 and Liverpool General Advertiser, 4 June 1773 and 14 October 1774.

79 The National Archives, London (hereafter TNA), Board of Trade records, muster rolls for the port of Liverpool, BT 98/35, 1775.
} 
colonial boycotts against British goods also achieved their intended outcome. Equally, restrictions imposed by Westminster in late-1775 restricted Liverpool's trading relationship with the colonists. Under the Prohibition of Trade Act, British vessels could still sail to America - but only if they received special licenses from the UK government. ${ }^{80}$ Evidence from mercantile manuscripts also suggests a deteriorating commercial environment. William Davenport, a prominent Liverpool merchant, corresponded with business associates in the West Indies. His records from the late 1770 s refer to disruptions in overseas communications, British vessels falling prey to privateers, and increasingly expensive marine insurance. The war with America was "cursed," and rendered more difficult by the subsequent interventions of France, Spain, and the Netherlands on the US side. ${ }^{81}$ Nevertheless, despite these difficulties, Liverpool continued to do business with America. British victories on the battlefield re-opened American towns to UK commerce. Consequently, individuals such as Liverpool merchant David Tuohy dispatched agents to the colonies to transact business. One such agent reported in 1781 that, despite the geographical limitations of British control in South Carolina, provisions of all kinds were "very much in demand."

Determining the impact of the American War upon canals in the Liverpool area is fraught with difficulty. Indeed, the financial accounts of these waterways have survived "in varying degrees of completeness." It is also hard to identify precisely what commodities were moved along these navigations, as extant records often lump a range of goods into broad categories. ${ }^{83}$ Nevertheless, in general, and despite some exceptions, it seems that during the war years these canals experienced only shortterm disruption - in the longer-term they overcame the disturbances in America. Any problems on these canals were due to a combination of wartime difficulties, and the internal dynamics on individual waterways.

The records for the aforementioned River Weaver are amongst the most complete for this period, and illustrate the pattern of short-term disruption during the American War, but a return to growth when peace was restored. The total annual tonnage for this waterway reached a high of 133,804 tons between 1772 and 1773 . Thereafter it declined, and reached a low of 90,851 tons for 1779-1780. Yet the figure rose to 144,231 tons between 1786 and $1787 .{ }^{84} \mathrm{~A}$ similar pattern was evident with the Weaver's toll revenues. Between 1774 and 1776 this figure stood at $£ 6,194$, and then declined to $£ 4,858$ in $1777-1779$. Thereafter it generally rose, reaching $£ 8,546$ in $1789-1791$. The decline in tonnage and revenue figures on the Weaver

\footnotetext{
${ }^{80}$ Bodleian Library, North Papers, North b.69.

${ }^{81}$ Merseyside Maritime Museum, Davenport Papers, Morson, Vance, Caldwell and Vance, Dominica, to William Davenport, Liverpool, D/DAV/10/7, 23 July 1777.

${ }^{82}$ Liverpool Record Office (hereafter LIVRO), Tuohy Papers, William Simmons, Charleston, South Carolina, to David Tuohy, 380 TUO/1/59, 27 December 1781.

83 Langton, "Liverpool and its hinterland in the late eighteenth century," 7-11.

${ }^{84}$ T.S. Willan, The Navigation of the River Weaver in the Eighteenth Century, (Manchester, 1951), 214-21.
} 
during the late-1770s coincided with the economic dislocation of the American conflict. Nevertheless, the drop in tonnage on the Weaver had begun prior to the start of the Revolutionary War in 1775. This suggests that competition from other nearby waterways, such as the Trent-Mersey, proved detrimental to the Weaver's business interests. Subsequent increases in tonnage and revenue along the Weaver were due to improvements on the waterway, and to rising demand for salt. ${ }^{85}$

The Bridgewater Canal also endured short-term disruption prior to longer-term growth during this period. Opened in the 1760s, during its early days the amount of coal transported along the Bridgewater was often "lower than the expectations aroused by the canal's reputation might have justified." This was due to competition from the Sankey Brook. Nevertheless, in the longer-term, the duke's "fortune was made." This was partially due to the expansion in carrying passengers. Indeed, the takings from this particular activity on the Bridgewater increased from $£ 1,303$ in $1776-1778$ to $£ 1,771$ in 1782-1784. Between 1788 and 1790 this figure rose to over $£ 2,000$. Total receipts on the Bridgewater Canal increased as well. From 1773 to 1775 this figure amounted to $£ 14,832$, and during the war years of 1779-1781 it was $£ 21,017$. By the end of the 1780 s the Bridgewater was earning over $£ 51,000$ per annum. ${ }^{86}$ Evidently the American War hardly affected the Bridgewater's longer term trajectory.

The Leeds-Liverpool Canal had originally been authorised in 1770, and by October 1774 (just a matter of months before the outbreak of the American revolt) the completed length between Wigan and Liverpool was opened. Nevertheless, no work was undertaken to extend the main line of the Leeds-Liverpool between 1777 and 1790. This was partially due to wartime conditions that restricted money supply. ${ }^{87}$ But the Leeds-Liverpool Canal Company had other problems too. Canal construction was obviously expensive, as it involved paying labourers and compensating inconvenienced landowners. ${ }^{88}$ The company purchased the Douglas Navigation in 1772 to boost the canal's water supply ${ }^{89}$ But this had proven a most expensive decision, and by 1784 the business was $£ 18,000$ in debt. ${ }^{90}$ Yet, in the longer-term, these difficulties proved surmountable. In 1781 the waterway's annual tonnage was 31,401 tons. A decade later it had risen to 45,616 tons. Unsurprisingly, the amount of coal transported along the Leeds-Liverpool also increased. Significantly, the amount of "merchandise" shipped along the waterway to

\footnotetext{
${ }^{85}$ Charles Hadfield and Gordon Biddle, The Canals of North West England Volume 1, (Newton Abbot, 1970), 51-3

${ }^{86}$ Ibid., 34-6.

${ }^{87}$ Mike Clarke, The Leeds and Liverpool Canal, (Preston, 1994), 84-5.

${ }^{88}$ TNA, Leeds and Liverpool Canal Company, Minutes of Liverpool Committee and General Assembly, RAIL 846/42, 1775-1780.

${ }^{89}$ Clarke, 75-6.

90 TNA, Leeds and Liverpool Canal Company, Minutes of Liverpool Committee and General Assembly, RAIL 846/43, 1781-1788.
} 
Liverpool increased from 347 tons in 1786 to 405 tons in $1788 .^{91}$ This presumably included manufactured products being sent from the British hinterlands for export to America. Combined, this evidence shows that the American War and the internal dynamics of local waterways threatened the economic connectivity between Liverpool and America. However, in the longer term, these problems were overcome by the restoration of peace.

\section{Economic Continuity and Change between 1783 and 1825}

Thus, after 1783, canals continued to facilitate economic interaction between Britain and America. A pamphleteer wrote some time after 1795 that "The advantage of these [Liverpool] CANALS must be obvious to every intelligent mind...they possess an uncommon share of the American Trade." 92 Yet the economic history of canals embodied another aspect of continuity in Anglo-American relations - the importance of British finance in America. H.V Bowen noted that prior to 1775, the colonists used metropolitan credit to meet short-term capital requirements. These funds originated from British state subsidies, as well as from private metropolitan and provincial investors in Britain. This money was spent on industrial enterprise (such as iron companies in New York and New Jersey during the 1760s), land speculation in Florida and Ohio, and on commodity trades such as tobacco. By the eve of the Revolution, the level of colonial indebtedness to Britain had increased. Domestic creditors were owed as much as $£ 3$ million by their colonial brethren. It has also been estimated that by 1791200 British firms were still owed roughly $£ 5$ million from the United States. ${ }^{93}$

After the war, the Americans still required capital to develop their country and internal improvements. This was fuelled by manufacturer's demands for primary products, such as cotton and tobacco. Toll roads, such as the one from Baltimore to Columbus, Ohio, had been federally financed. However, it proved to be a failure. Critics charged that the federal government should stay out of internal improvements, and that state governments should become more involved. ${ }^{94}$ To that end, in 1817 New York financed the Erie Canal by issuing state canal bonds.

\footnotetext{
91 LIVRO, Holt and Gregson Papers Volume 10, Annual tonnage along the Leeds-Liverpool Canal, $942 \mathrm{HOL} / 10$.

92 Ibid.

93 H.V. Bowen, Elites, Enterprise and the Making of British Overseas Empire 1688-1775, (Basingstoke, 1996), 80-94.

${ }^{94}$ Kathleen Burk, Old World, New World: The Story of Britain and America, (London, 2007), 3134. For more on the predominance of state canal initiatives over federal during the early-nineteenth century see Carter Goodrich, Government Promotion of American Canals and Railroads 18001890, (New York, 1960), John Lauritz Larson, “'Bind the Republic Together': The National Union and the Struggle for a System of Internal Improvements," Journal of American History, 74, 2 (1987), 363-87 and Jay Sexton, Debtor Diplomacy: Finance and American Foreign Relations in the Civil War Era 1837-1873, (Oxford, 2005), 18-9.
} 
Regardless, Governor DeWitt Clinton surmised that foreigners held two thirds of the New York canal stock. ${ }^{95}$ By 1822 half of the canal loans issued by New York state were held by Britons. ${ }^{96}$ Furthermore, by 1836 , the bulk of the remaining $\$ 3.5$ million debt on the Erie Canal was held by foreigners - the majority of which were British citizens. ${ }^{97}$ Evidently, investment from the former mother country enabled New York to issue debt with favourable interest rates. ${ }^{98}$ When Ohio state leaders inquired if New York would offer financial support for their own project to construct a canal between the Ohio River and Lake Erie, New York politicians directed them towards London money markets. ${ }^{99}$ The "revelation that states could borrow money in London," as one economic historian puts it, led to the bulk of foreign capital invested in canals and railways in the northern US before 1836 (roughly $\$ 4.5$ million dollars) being procured from Britain. ${ }^{100}$

Thus, to a great extent, the Erie Canal was financed by British investors - even if this was seldom direct. If an importer bought British goods, it was safer to pay in bonds than gold. An American importer might buy bonds issued by the New York state to pay for the canal, then send them to London as payment for goods. These bonds were successful, as interest was promptly paid. On the whole, the result was a burst of enthusiasm in London for American state securities. The total British capital invested in American securities during the 1830s was roughly equivalent to the states' debts. By 1835 this invested capital was $\$ 66$ million. Three years later it was $\$ 174$ million. ${ }^{101}$ Many Americans viewed the financial role of the former mother country in US canal construction with suspicion. Even President Madison cast waterways as facilitators for the importation of British capital, which constituted "a foreign poison vitiating the American sentiment, [and] recolonizing the American character." ${ }^{102}$

Thus, in a bid to counteract this perceived threat from British money, there were movements towards the public financing of many American canals - which was a significant departure from the British approach of chartering private canal companies. As early as 1807, the Erie Canal advocate Jesse Hawley opposed the incorporation of private companies to build canals. He wrote: "Should British agents and capitalists purchase up the major part of it, our government would become

\footnotetext{
${ }^{95}$ DeWitt Clinton to Mathew Carey in Columbia University Rare Book and Manuscript Library, DeWitt Clinton Papers, vol. 21, 23 October 1824.

${ }^{96}$ Nathan Miller, The Enterprise of a Free People: Aspects of Economic Development in New York State During the Canal Period, 1792-1838, (Ithaca, 1962), 105.

${ }^{97}$ Ibid., 110.

${ }^{98}$ Ibid., 111.

99 DeWitt Clinton to Micajah T. Williams, 8 November 1823 and Cadwallader D. Colden to Micajah T. Williams, 10 November 1823 in Civil Engineer, and Herald of Internal Improvement, I, $6(1828), 85-89$.

${ }^{100}$ Leland Hamilton Jenks, The Migration of British Capital to 1875, (New York, 1927), 74-5.

101 Burk, 314-5

102 "Foreign Influence" in The Papers of James Madison Digital Edition, J.C.A. Stagg, (ed.)

(Charlottesville, 2010), http://rotunda.upress.virginia.edu/founders/; accessed 25 February 2015.
} 
completely manacled with foreign control."103 Americans feared that republicanism, if not the very independence of the United States, could be undercut by British money. DeWitt Clinton later advised the state of New Jersey to undertake canal construction itself, as opposed to delegating projects to private canal companies. These entities, Clinton warned, would draw capital from abroad and the state "will be bound hand and foot by the shackles of a non-resident company." 104 True, US projects during the late eighteenth century had attempted to replicate the British model of private financing through canal corporations. But they often met with limited success, owing to provincial concerns, the lack of expertise, and the inability to convince Americans to invest in their projects. ${ }^{105}$ Henceforth, major nineteenth century projects (starting with the Erie Canal in 1817) were often financed through public debt (admittedly drawing in British capital with state bonds). But many Americans opposed the British model of using private company stock to fund canal construction.

\section{Conclusions}

This article has looked at canals in Britain and America between 1763 and 1825 in a trans-Atlantic context. We show that canals on both sides of the Atlantic mirrored the connectivity, continuity, and change, in Anglo-American relations during this era. This was manifested in socio-cultural interaction. Indeed, writings by American travellers in the UK prior to the Revolution indicate that these individuals viewed and travelled along British canals. Henceforth, they gained information about these waterways, and transferred this knowledge back to the colonies. Other colonial travellers expressed a sense of pride in British canal building, and experienced a common sense of belonging with the mother country. Even after 1783, early US canal progenitors continued to draw technical inspiration from their British counterparts. However, Americans now sought to out-perform the former mother country in canal building (even though the means to facilitate US independence reinforced persisting social and cultural links with Great Britain).

A second key role played by canals in Anglo-American relations during this period was economic. The Liverpool case study showed that local canals transported American raw materials from British ports to their hinterlands for manufacturing. In return, British manufactures were sent along canals, and then loaded on board vessels bound for America. The War of Independence, as well as the internal

\footnotetext{
103 Jesse Hawley, "Hercules VII" in David Hosack, Memoir of Dewitt Clinton: With an Appendix, Containing Numerous Documents, Illustrative of the Principle Events of His Life (New York, 1829), 325.

104 DeWitt Clinton to George P. McCulloch, Charles Kinsey, and Thomas Capner, 24 October 1823 in Hosack, Memoir of DeWitt Clinton, 215.

105 John Lauritz Larson, Internal Improvement: National Public Works and the Promise of Popular Government in the Early United States (Charlotte, 2001), chapter 1.
} 
dynamics of British waterways, threatened to disrupt this economic nexus. Nevertheless, the conflict did not stop overseas trade entirely, and after 1783 British canals continued to be involved in the transportation of manufactured goods bound for the US. In addition, during the post-war years, the early republic continued to rely heavily upon British finance. However, Americans sought to counter perceived threats of being re-colonised by British money. So they shifted away from the British model of using private canal companies, and subsequently channelled funds for waterway construction through accountable US state governments. 